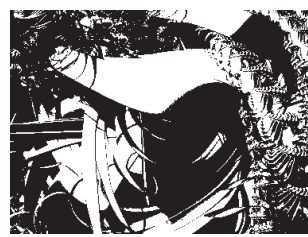

\title{
SUCCESSION STATUS OF ORGANIC AND CONVENTIONAL FAMILY FARMS IN SOUTHWESTERN SLOVENIA
}

Zaria BOHAK, Andreja BOREC, Jernei TURK

Faculty of Agriculture and Life Sciences, Hoče, Slovenia

UDK: 338.439(497.4-14) $631.1 .017 .1(497.4-14)$

Prethodno priopćenje

Primljeno: 19. 4. 2010.

To assure long term survival of family farms, well regulated farm succession is of vital importance. This is a complex process where many factors influence the final event, the ultimate transfer of family farm from older to younger generation. In addition, organic agriculture is also becoming an increasingly important factor for the future existence of the family farm. The aim of this paper is to analyse 17 conventional and 30 organic family farms from the Southwestern part of Slovenia regarding their current succession status in order to find out which group of farms has better current succession status. The methodology was based on the decision analysis technique, DEX, an expert system shell for qualitative decision modelling and support. The multi-attribute decision model was developed and applied to the family farms data, obtained by the use of a standardized questionnaire on the family farm succession process. The results confirm our assumption and indicate that organic farms have a better succession situation.

Keywords: family farm succession, organic farms, DEX methodology, multi-criteria decision model

$\triangle$ Zaria Bohak, University of Maribor, Faculty of Agriculture and Life Sciences, Pivola 10, 2311 Hoče, Slovenia.

E-mail: zarja.bohak@uni-mb.si

\section{INTRODUCTION}

In Slovenia, organic farming has to be understood as a more viable alternative comparing to more conventional approaches to agriculture (Pažek and Rozman, 2007a). Many farmers are 
DRUŠ. ISTRAŽ. ZAGREB GOD. 20 (2011) BR. 4 (114),

STR. 1183-1199

BOHAK, Z., BOREC, A. TURK, J.:

SUCCESSION STATUS shifting from conventional to organic farming as it became a good market niche and for many farmers the only way for survival due to policy support aids. On the other hand, many researches (Fennell, 1981; Dežman, 1988; Barbič, 1991; Potter and Lobley, 1992; Gasson and Errington, 1993; Kovačič, 1996; Errington, 1998; Kerbler, 2003; Barbič, 2005; Bohak, 2006; Kerbler, 2007; Calus et al., 2008) pointed out that the farm succession process remains critical for the continued existence and development of each family farm regardless of the production orientation. Family farm succession is not an easy task, neither for the farm operators nor for the successor. It is a complex process which may last for a decade (Potter and Lobley, 1992).

The review of the literature reveals that certain researches (Chamberlain et al., 1999; Mäder et al., 2002; Oehl et al., 2004; Hole et al., 2005; Stopes et al., 2002; Olesen et al., 2006) compare and evaluate organic and conventional farms in relation to their impact on the environment (soil, biodiversity). There is also a lot of researches (Michelsen, 1996; Cederberg and Mattsson, 2000; Lansink et al., 2002; Offermann and Nieberg, 2008) exploring the production practises and financial and market efficacy of both approaches to agriculture. In most cases, the organic farms were rated better than the conventional. But there is no literature which investigates whether organic is better than conventional farm also regarding their succession status, which is a strong indicator of farm viability.

In this paper, 17 conventional and 30 organic farms from Slovene Coastal landscapes (Southwestern part of Slovenia) are analysed. The evaluation of farms was made in order to find whether organic farms have not only better market and ecological status but also better present succession status than conventional. This study is a pilot study, performed in order to check the presented methodology, which has never been used in studying the family farm succession process.

The research methodology is based on the qualitative multi-attribute (also multi-criteria) decision modelling methodology DEX (Bohanec and Rajkovič, 1990). To evaluate succession status of each family farm from Coastal landscapes, the qualitative multi-attribute decision model DEX was developed and applied to the family farms data. In addition, the model results were tested by Chi-square test in order to obtain statistically supported results.

The article is organized as follows. First, the data sources and the study area were defined. Then the multi-attribute decision making process and the development of the multi-attribute decision model were described in section 2 . Section 3 presents and discusses the results of organic and conventional farms' current succession status. The conclusions are in section 4 . 
According to Marušič et al. (1993), Slovenia is divided into 5 basic landscape areas: Alpine landscapes, Subalpine landscapes, Slovenian subpanonian landscapes, Karst landscapes of interior Slovenia and Coastal landscapes. The study comprises 215 farms from the whole of Slovenia; 40 to 47 from each landscape area.

Family farms data were obtained by applying the standardized questionnaire developed at Plymouth University in Great Britain and used for FARMTRANSFERS database. ${ }^{1}$ The questionnaire consists of three different sections. The first one refers to structural characteristics of farm household and farm family. The second one describes farm operator's plans on farm transfer, while the third one refers to the farm successor. The questions are of closed and semi-closed type; there are 28 questions in total.

The survey of individual farms was conducted in the frame of "face to face" interviews. Questionnaires were carried out in the years 2008 and 2009. The interview of each farm lasted one to two hours approximately. The examiner was an adequately trained person. Respondents were current farm operators. The intention of farmers and actual succession may differ from each other but the standardized questionnaire does not envisage the next generation as the respondents. Some farm operators did not want to answer all the questions and in this case such a questionnaire was rejected. But in total, more than 200 suitable questionnaires were acquired in order to study the farm succession process.

The pilot study, described in this paper, presents the results of all 47 randomly chosen family farms from Slovene Coastal landscapes (Southwestern part of Slovenia). According to farmers' answers, 17 farms are conventional and 30 are organic. The sample of farms from these landscapes has been chosen in order to obtain results at the regional level. At the same time, the Coastal landscapes area is the first one in a series of succession analyses from all other Slovenian landscape areas.

The obtained answers were used as input data for the multi-attribute model. In order to better distinguish between farms, the organic ones were marked with the word ORG and

1 FARMTRANSFERS database is a network of collaborating countries, based on signed Memorandum of Understanding for Farm Succession Research. conventional with the word $\mathrm{CON}$, and also with numbers, from ORG 1 to ORG 30 and from CON 1 to CON 17, according to their production orientation. In the sample of both, organic and conventional farms, vineyard and fruit growing farms predominate (more than $80 \%$ ), although there is also a smaller percentage of livestock oriented and mix enterprise farms. 


\section{Multi-attribute decision analysis and DEX methodology}

Decision problems are in general problems of choice and their main characteristic is to choose the best option within the given set of options (Bohanec, 2008), while the factors influencing the choice are many and varied.

Decision analysis is the approach which offered a number of methods and techniques for analyzing and solving complex decision problems (Triantaphyllou, 2000). The most common decision-making analysis techniques are based on building of hierarchical decision-making trees and multi-attribute decision models (Bohanec, 2008). For the latter, the technique of multi-attribute decision analysis enables the decomposition of the complex problems or attributes to smaller, less complex, more manageable subproblems (Pažek and Rozman, 2007b), which are therefore organized hierarchically and connected with the utility function.

In this study, the DEX methodology, a representative of the qualitative (symbolic) multi-attribute methods (Pažek and Rozman, 2007b), was applied and according to this method, multi-attribute decision model DEXi was developed. The most typical feature of DEX method is to use numerical rather than symbolic-descriptive parameters (attributes), such as "low", "high", "good", "bad", "acceptable", "excellent", etc. Another important feature of the DEX method is the ability to use inexact, inaccurate or even missing data (Bohanec and Rajkovič, 1999).

To assess succession status of family farms, the multi-attribute decision DEXi model was developed. The role of the model is to take data, obtained by the questionnaire and use them to make a final evaluation of farm succession status according to the hierarchical structure of the attributes (Fig. 1). The model consists of three components: attributes, scales and utility functions (Bohanec et al., 2000).

The entry components of the model are the so-called attributes (parameters, criteria). These are the variables that represent decision subproblems and determine the quality of alternatives. According to their position in the model, attributes can be basic and aggregate. Their values are qualitative, usually represented by words rather than numbers, for example "high", "perspective", "bad", etc. In DEXi model, each attribute is determined with its name and scale.

Basic attributes are connected with the utility function into aggregate attributes. The utility function is the "if-then" decision rule that identifies the impact of lower-lying attributes to those that lay higher. For instance, a decision rule can be: "if the farm successor is living on the farm, then the succession status on the farm is good". In contrast, more common qualitative multi-attribute decision models use utility functions that 
DRUŠ. ISTRAŽ. ZAGREB GOD. 20 (2011), BR. 4 (114)

STR. 1183-1199

BOHAK, Z., BOREC, A., TURK, J.:

SUCCESSION STATUS... employ weights, such as weighted sum (Rozman et al., 2009). Each alternative (family farm) is described by the value of each attribute and the utility functions serve for the overall evaluation of the alternative. It means that family farms data are entered at the bottom of the hierarchy and are gradually aggregated in a bottom-up way through a series of aggregate attributes until the final evaluation of succession status on each farm.

The computer software DEXi 3.01 was used for the development of the multi-attribute decision DEXi model. The computer programme is based on the DEX methodology and has been developed at the Institute Jozef Stefan (Jereb et al., 2003).

\section{DEXi model for the assessment of family farm present succession status}

The initial form of the hierarchical DEXi model was established through the review of home and foreign empirical studies on family farm succession. Furthermore, the answers obtained from the questionnaires, served as guidelines for the assessment of the importance of individual attribute and for utility function formulation. The final hierarchical structure of the DEXi model for family farm succession status evaluation is shown in Figure 1.

The problem of family farm succession status evaluation is based on three levels:

- the first level is presented by aggregate attributes Family farm, Farm operator and basic attribute Successor;

- at the second level, the attribute Family farm is decomposed to the aggregate attributes Property structure and Farm family. The attribute Farm operator is decomposed into the aggregate attributes (farmer's) Personal characteristics and (farmer's) Plans and opinions. The attribute Successor is not divided furthermore;

- at the third level, the attribute Farm family is divided into aggregate attribute Children and basic attribute Tradition. Other aggregate attributes from the second level and aggregate attribute Children are decomposed to 11 basic attributes.

A more detailed description of each attribute is shown in Figure 1. Each attribute is defined by its name and scale (Figure 2). According to Bohanec (2008), a scale represents a set of qualitative and discrete values and can be ordered or unordered. Due to easier definition of utility function, scales in the presented model are ordered and increasing - from bad (bold writing in Figure 2) through medium (normal writing) to good value (bold and italic writing) of each attribute. Scales were defined according to the results of many home and for- 
DRUŠ. ISTRAŽ. ZAGREB GOD. 20 (2011)

BR. 4 (114)

STR. 1183-1199

BOHAK, Z., BOREC, A., TURK, J.:

SUCCESSION STATUS

$\rightleftharpoons$ FIGURE 1

The hierarchical

structure of the model eign studies on the family farm succession process. For instance, we decided to include in the model the number of sons but not the number of daughters as the concept of primogeniture in Slovenia still exists. This concept is composed of three distinct elements, ownership is transferred to one person, that person is male and he is the first born son (Gasson and Errington, 1993). Also Kimhi and Nachlieli (2001) and Glauben et al. (2004) argued that the number of sons has a stronger effect on the probability of succession than the number of daughters, due to the concept of sons as preferred successors. Similar results are reported by Kerbler (2007). He found a strong and positive impact of the number of sons (but not the number of daughters) on the succession status and decisions on farms.

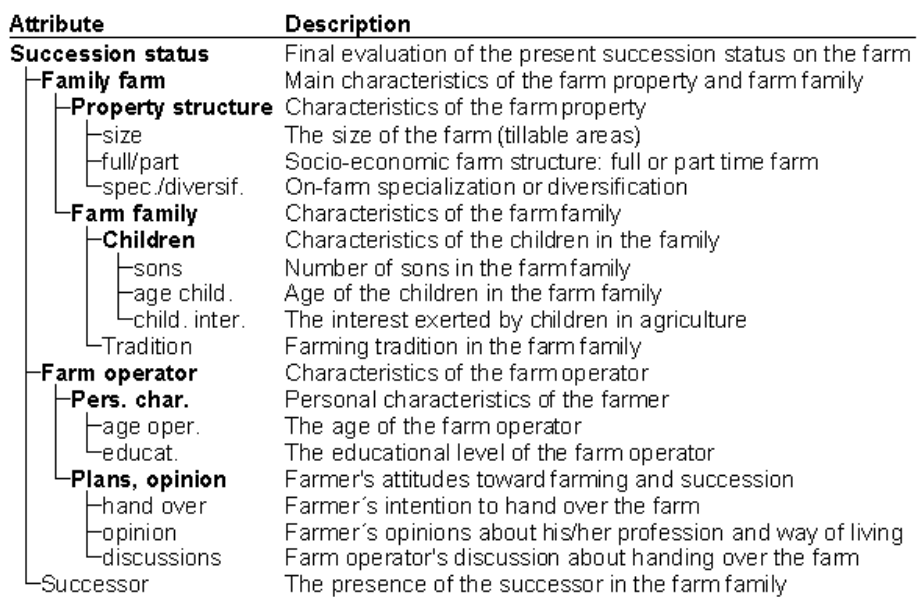

- FIGURE 2

Scales of the attributes

\begin{tabular}{|c|c|}
\hline Attribute & Scale \\
\hline Suc cession status & very bad; bad; medium; good; v. good \\
\hline Family farm & unpersp.; less persp.; persp ; v. persp. \\
\hline -Property structure & unpersp.; less persp; persp ; v. persp. \\
\hline -size & sm all $(<5 \mathrm{ha})$ med. $(5-10)$ big $(10 \mathrm{ha})$ \\
\hline -full/part & part; full \\
\hline$L_{\text {spec/diversif }}$ & spec. ; divers. \\
\hline Farm family & unpersp ; I. persp; persp ; v. persp. \\
\hline -Children & inapprop.; approp ; v. approp. \\
\hline Esons & $0 ; 1 ; 2$ or more \\
\hline - age child. & $>40$; no child, f.o. $<60 ;$ up to 40 \\
\hline$L_{\text {child. inter. }}$ & noino child, f. $0 .>60$; undef/no-small child, f.o. $<60$; yes \\
\hline LTradition & no; yes \\
\hline $\begin{array}{l}\text {-Farm operator } \\
\text {-Pers. char. } \\
\text {-age oper. }\end{array}$ & $\begin{array}{l}\text { inapprop.; less approp.; approp.; v. approp. } \\
\text { inapprop.; I. approp.; approp.; v. approp. } \\
>65 ; \Rightarrow 65\end{array}$ \\
\hline Leducat. & $\begin{array}{l}\text { high; low/mid non-agric; low/mid agric. } \\
\text { inapprop.; less approp.; approp.; v. approp. }\end{array}$ \\
\hline Hhand over & no; yes \\
\hline $\begin{array}{l}\text {-opinion } \\
\text { discussions }\end{array}$ & $\begin{array}{l}\text { neg.; neutr.; posit. } \\
\text { no one, no intention; family OR adviser; family AND adviser }\end{array}$ \\
\hline Lsuccessor & no; probably, yes \\
\hline
\end{tabular}


DRUŠ. ISTRAŽ. ZAGREB GOD. 20 (2011),

BR. $4(114)$

STR. 1183-1199

BOHAK, Z., BOREC, A., TURK, J.:

SUCCESSION STATUS..

FIGURE 3

Decision rules (utility functions) for aggregate attribute Succession status

\begin{tabular}{|c|c|c|c|c|}
\hline & Family farm & Farm operator & Successor & Succession status \\
\hline & $35 \%$ & $29 \%$ & $36 \%$ & \\
\hline 1 & unpersp. & inapprop. & $<=$ probably & very bad \\
\hline 2 & unpersp. & $<=l e s s$ approp. & no & very bad \\
\hline 3 & $<=$ less persp. & inapprop. & no & very bad \\
\hline 4 & unpersp. & inapprop. & yes & bad \\
\hline 5 & unpersp. & less approp. & probably & bad \\
\hline 6 & unpersp. & $>=$ approp. & no & bad \\
\hline 7 & less persp. & inapprop. & probably & bad \\
\hline 8 & less persp. & less approp. & no & bad \\
\hline 9 & persp. & inapprop. & no & bad \\
\hline 10 & unpersp. & less approp.:approp. & yes & medium \\
\hline 11 & $<=$ ess persp. & less approp. & yes & medium \\
\hline 12 & unpersp. & approp. & $>=$ probably & medium \\
\hline 13 & unpersp. & $>=$ approp. & probably & medium \\
\hline 14 & $<=$ less persp. & approp. & probably & medium \\
\hline 15 & less persp. & $<=$ less approp. & yes & medium \\
\hline 16 & less persp..persp. & inapprop. & yes & medium \\
\hline 17 & less persp. & less approp. & >=probably & medium \\
\hline 18 & less persp. & less approp.: approp. & probably & medium \\
\hline 19 & less persp .persp. & less approp. & probably & medium \\
\hline 20 & less persp. & approp. & $<=$ probably & medium \\
\hline 21 & less persp. & >=approp. & no & medium \\
\hline 22 & less persp..persp. & approp. & no & medium \\
\hline 23 & persp. & inapprop. & $>=$ probably & medium \\
\hline 24 & persp. & $<=$ less approp. & probably & medium \\
\hline 25 & $>=$ persp. & inapprop. & probably & medium \\
\hline 26 & persp. & less approp. & $<=$ probably & medium \\
\hline 27 & persp. & less approp.:approp. & no & medium \\
\hline 28 & $>=$ persp. & less approp. & no & medium \\
\hline 29 & v. persp. & inapprop. & $<=$ probably & medium \\
\hline 30 & v. persp. & $<=l$ ess approp. & no & medium \\
\hline 31 & $<=$ less persp. & v. approp. & yes & good \\
\hline 32 & less persp. & >=approp. & yes & good \\
\hline 33 & less persp..persp. & approp. & yes & good \\
\hline 34 & less persp. & v. approp. & $>=$ probably & good \\
\hline 35 & less persp..persp. & v. approp. & probably & good \\
\hline 36 & persp. & less approp.: approp. & yes & good \\
\hline 37 & $>=$ persp. & less approp. & yes & good \\
\hline 38 & persp. & approp. & s=probably & good \\
\hline 39 & persp. & >=approp. & probably & good \\
\hline 40 & > =persp. & approp. & probably & good \\
\hline 41 & persp. & v. approp. & $<=$ probably & good \\
\hline 42 & $>=$ persp. & v. approp. & no & good \\
\hline 43 & v. persp. & less approp. & $>=$ probably & good \\
\hline 44 & v. persp. & less approp.:approp. & probably & good \\
\hline 45 & v. persp. & approp. & $<=$ probably & good \\
\hline 46 & v. persp. & >=approp. & no & good \\
\hline 47 & $>=$ persp. & v. approp. & yes & V. good \\
\hline 48 & v. persp. & inapprop. & yes & v. good \\
\hline 49 & v. persp. & $>=$ approp. & yes & v. good \\
\hline & & & & \\
\hline
\end{tabular}

In the final phase of model development, the utility functions (decision rules) were defined according to cognitions of other studies on family farm succession. Utility function connects all the combinations of the third level attributes values through the attributes from the second level to attributes of the first level and the root attribute (final evaluation, Succession status). Therefore, the utility function has to be defined for all combinations of aggregate attributes, including the root. In this model, there are 8 utility functions in total. In Figure 3 , the example of the utility function that connects two aggregate attributes (Family farm and Farm operator) and basic attribute Successor into the overall evaluation of farm Succession status is presented. At the top of the table the relative im- 
DRUŠ. ISTRAŽ. ZAGREB GOD. 20 (2011),

BR. 4 (114),

STR. 1183-1199

BOHAK, Z., BOREC, A., TURK, J.:

SUCCEESSION STATUS... portance of the attributes is expressed by weights (family farm $35 \%$, farm operator $29 \%$ and successor $36 \%$ ). They have been estimated from the rules by the DEXi programme using a linear regression method (Bohanec, 2008; Rozman et al., 2009). Figure 3 shows complex rules which are obtained by joining several elementary rules which have the same function value (Bohanec, 2008, 14). The symbol $>=$ means "equal or better" value and the symbol $<=$ means "equal or worse" value of the attribute. For example, rule number 2 has dictated that if the value of the attribute Family farm is "unperspective" and the attribute Farm operator is "less appropriate or worse" and there is "no" Successor on the farm, then the Succession status on the farm is "very bad".

\section{RESULTS AND DISCUSSION}

The farm succession status evaluation was analyzed on 17 conventional farms and 30 organic farms using the developed DEXi model. The farms data were obtained from the standardized questionnaire. The farmers' answers were taken into the model as the value of each corresponding input (basic) attribute. Figure 4 represents this procedure for 5 organic farms.

$\rightarrow$ FIGURE 4

Input data (basic attributes) obtained from standardized questionnaire for 5 organic farms

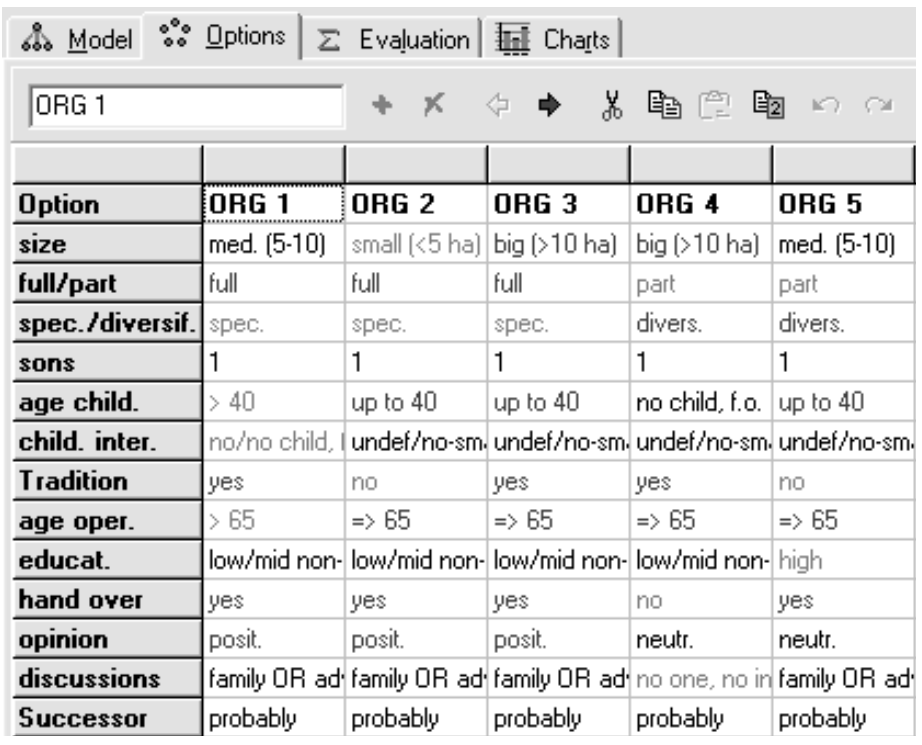

For instance, data (basic attributes) for farm ORG 1, gathered from the questionnaire, are as follows: the farm is medium sized, full-time farm, there is on farm specialization, there is one son on the farm, children on the farm are over 40 years old, they exert no interest for farming, there is farming tradition in the farm family, farm operator is over 65 years old, farm operator has low or middle non-agricultural education, farm operator has an intention to hand over the farm before 
DRUŠ. ISTRAŽ. ZAGREB GOD. 20 (2011), BR. $4(114)$

STR. 1183-1199

BOHAK, Z., BOREC, A., TURK, J.:

SUCCESSION STATUS..

FIGURE 5

Results of DEX evaluation of 5 organic farms, showing all the values of basic and aggregate attributes he/she dies, farm operator has positive opinions about farming, his/her way of living and succession, farm operator discusses farm succession with family members or adviser and there is potential successor on the farm. According to the scale (Figure 2), each of these data has good, medium or negative value. For example, medium sized farm means neutral value, full-time farm means good value and farm operator more than 65 years old means bad value. The same procedure was used for all farms and for all basic attributes.

\begin{tabular}{|c|c|c|c|c|c|}
\hline$\therefore$ Model $\because \because$ Options & $\Sigma$ Evaluati & tion | 重 Cha & & & \\
\hline & 酔 & $1 \stackrel{\equiv}{\equiv}$ & $\triangle$ & & \\
\hline & & & & & \\
\hline Option & ORG 1 & ORG 2 & ORG 3 & ORG 4 & ORG 5 \\
\hline Succession status & good & medium & good & good & very bad \\
\hline . Family farm & persp. & unpersp. & persp. & ч. persp. & unpersp. \\
\hline . . Property structure & persp. & unpersp. & ૫. persp. & persp. & less persp \\
\hline . . . size & med. $(5-10)$ & small $[<5 \mathrm{ha}]$ & big (>10 ha) & big ( $>10$ ha) & med. $(5-10)$ \\
\hline .... full/part & full & full & full & part & part \\
\hline . . . spec./diversif. & spec. & spec. & spec. & divers. & divers. \\
\hline ... Farm family & unpersp. & persp. & persp. & persp. & persp. \\
\hline .... Children & inapprop. & approp. & approp. & approp. & approp. \\
\hline$\ldots .$. sons & $1 /$ no sons, f. & $1 /$ no sons, f. & $1 /$ no sons, f. & $1 /$ no sons, f. & $1 /$ no sons, f. \\
\hline$\ldots \ldots$ age child. & $>40 /$ no chilc & $=$ up to 40 & up to 40 & no child, f.o. & up to 40 \\
\hline . . . . child. inter. & no/no child, I & lundef/no-sm. & undef/no-sm. & undef/no-sm. & indef/no-sm. \\
\hline .... Tradition & yes & no & yes & yes & no \\
\hline . Farm operator & approp. & v. approp. & ४. approp. & approp. & inapprop. \\
\hline ... Pers. char. & inapprop. & ч. approp. & צ. approp. & ч. approp. & inapprop. \\
\hline ... . age oper. & $>65$ & $\Rightarrow 65$ & $\Rightarrow 65$ & $\Rightarrow 65$ & $\Rightarrow 65$ \\
\hline .... educat. & low/mid non- & low/mid non- & low/mid non- & low/mid non- & high \\
\hline ... Plans, opinion & ₹. approp. & マ. approp. & צ. approp. & inapporp. & approp. \\
\hline .... hand over & yes & yes & yes & no & yes \\
\hline .... opinion & posit. & posit. & posit. & neutr. & neutr. \\
\hline$\ldots$. discussions & family OR ad. & | family OR a & f family OR ad. & no one, no & family OR ad. \\
\hline . Successor & probably & probably & probably & probably & probably \\
\hline
\end{tabular}

After this procedure, the assessment of the succession status on each farm was made by the DEXi model. A part of the results is shown in Figure 5. According to the decision rules, 13 basic attributes were combined to aggregate attributes. In this way, values of basic attributes hand over ("yes"-good value), opinions ("positive"-good value) and discussions ("family OR adviser"-medium value) contribute to "very appropriate" aggregate attribute Plans, opinions of farm operator from farm ORG 1. Similarly, values of basic attributes age oper. and educat. contribute to "inappropriate" aggregate attribute Personal characteristics of farm operator from farm ORG 1 . "Very appropriate" value of aggregate attribute Plans, opinions and "inappropriate" value of aggregate attribute Personal characteristics according to decision rules means "appropriate" value of aggregate 
DRUŠ. ISTRAŽ. ZAGREB GOD. 20 (2011)

BR. 4 (114),

STR. 1183-1199

BOHAK, Z., BOREC, A. TURK, J.:

SUCCESSION STATUS attribute Farm operator from farm ORG 1. The same procedure was used for evaluation of other aggregate attributes: values of basic attributes child inter., age child. and sons contributed to the "inappropriate" value of aggregate attribute Children. Children together with basic attribute Tradition contribute to the "unperspective" value of aggregate attribute Farm family. On the same level basic attributes size, full/part and spec./diversif. contribute to "perspective" value of aggregate attribute Property structure, which, together with aggregate attribute Farm family, create "perspective" value of aggregate attribute Family farm. Finally, according to the decision rules represented in Figure 3, the value of "good" Succession status of farm ORG 1 was obtained from "perspective" value of attribute Family farm, "appropriate" value of attribute Farm operator and "probably" value of attribute Successor. The same procedure was used for evaluation of succession status of all 47 farms.

Final evaluation of farm succession status of all 47 farms is shown in Table 1. According to the model structure (Figure 1) and decision rules (Figure 3 ) it is evident that farms may receive 5 different marks of their current succession status: "very bad", "bad", "medium", "good" and "very good".

Table 1 reveals that 5 conventional farms received the worst evaluation - "very bad" succession status, 2 farms have "bad" current succession status, 3 have "medium" succession status, 1 farm has "good" succession status and 6 conventional farms have "very good" present succession status. Similarly, succession status of 3 organic farms is evaluated as "very bad", 1 farm has "bad" and 3 have "medium" succession status. 12 organic farms received "good" and 11 organic farms received "very good" evaluation of their current succession status.

It is worth mentioning that the results are not absolute and only shed light upon the momentary succession situation on each farm, which may change over time due to different internal and external factors. But if the succession situation does not change, "very good" evaluated farms will have the biggest possibilities for future farm survival. Family farms evaluated as "good" are probably quite unstable as regards their good succession status but stand a solid chance of changing their succession status to "very good" and increasing their possibilities for future survival. Within the group of "medium" evaluated farms, there are probably candidates for survival and decay. Farms that have been evaluated as "bad" probably have only few opportunities to improve their succession status and thus only few opportunities for their future survival exist while farms assessed as "very bad" probably have no opportunities to improve their final succession status and will most likely decay. 
(1) TABLE 1

The result of the Chi-square test: differences between conventional and organic farms as regards their DEXi evaluations
At first glance it seems that organic farms have received better overall evaluation of succession status. To test this assumption, Chi-square test was made. The results of the model were applied to the statistical computer programme and are evident from Table 1.

\begin{tabular}{llrrrrrr}
\hline \multirow{2}{*}{ Conv. /Org. farm } & & & \multicolumn{5}{c}{ DEXi evaluation of succession status } \\
& & Very bad & Bad & Medium & Good & Very good & Total \\
\hline \multirow{2}{*}{ Conventional farm } & $\mathrm{f}$ & 5 & 2 & 3 & 1 & 6 & 17 \\
& $\mathrm{f} \%$ & 29.4 & 11.7 & 17.6 & 6.0 & 35.3 & 100.0 \\
Organic farm & $\mathrm{f}$ & 3 & 1 & 3 & 12 & 11 & 30 \\
\multirow{2}{*}{ Total } & $\mathrm{f} \%$ & 10.0 & 3.3 & 10.0 & 40.0 & 36.7 & 100.0 \\
& $\mathrm{f}$ & 8 & 3 & 6 & 13 & 17 & 47 \\
\multirow{2}{*}{ Test result } & $\mathrm{f} \%$ & 17.0 & 6.4 & 12.8 & 27.6 & 36.2 & 100.0 \\
& $\chi^{2}=9.666^{*}, \mathrm{p}=0.046$ & & & & & \\
\hline
\end{tabular}

* As the frequencies of farms are very low, the Likelihood Ratio was taken into consideration.

From Table 1 it can be gleaned that almost $30 \%$ of conventional farms received the worst evaluation "very bad" in contrast to only $10 \%$ of organic farms. On the other hand, a similar share of both groups of farms got the best evaluation "very good" (35.5\% and $36.7 \%)$, but only $6 \%$ of conventional farms were evaluated as "good" in contrast to $40 \%$ of organic farms. The differences between both groups of farms are statistically significant $(p<0.05)$ and indicate that organic farms have better momentary succession status than conventional farms.

A closer look at the evaluation results of both groups of farms explains why organic farms in general got better succession status than conventional ones (Table 2).

The DEXi evaluation results indicated that organic farms have a better property structure. According to the model components, better property structure means that farms are bigger and mostly full-time. The share of unperspective farm families, where (according to model structure) children show no interest in agriculture and are too old for successful takeover of the farm, is smaller in organic farms. The share of perspective and very perspective farm families is bigger in organic farms. As regards farm operators, organic farms have a bigger share of farm operators with appropriate and very appropriate personal characteristics (farm operator is not too old and has appropriate education) and a smaller share of farmers with inappropriate personal characteristics.

It is also interesting to note that the difference between organic and conventional farms lies in the minds of the farmers. The share of "organic" farmers that got the evaluation of 
DRUŠ. ISTRAŽ. ZAGREB GOD. 20 (2011),

BR. 4 (114),

STR. 1183-1199

BOHAK, Z., BOREC, A. TURK, J.:

SUCCESSION STATUS

(1) TABLE 2

Results of DEXi evaluation showing the values for all farms and for three main attributes his/her "very appropriate" plans and opinions is bigger than the share of "conventional" farmers. According to the model structure, this evaluation means that farmers from organic farms are more confident about farming as a way of living and they discussed succession plans more than their counterparts. They also believe more in the future of family farming and have a stronger intention to hand over their farm in time. Maybe we could also assume that these differences are the reason for conversion to organic? Clearly, there is the "cause and effect" question: is conversion to organic the effect or the cause of these thoughts?

Organic farms did also better in the case when the attribute Successor was evaluated. A bigger share of organic farms has definitively appointed a successor, while the successor on most of the conventional farms has probably not yet been defined.

The sample of farms is small, particularly the sample of conventional farms. It is quite possible that a more equal ratio between both samples of farms would change the results, but the presented findings indicate that there are differences between organic and conventional farms also when succession status is examined.

\begin{tabular}{|c|c|c|c|}
\hline & Attribute & $\begin{array}{l}\text { Conventional farms } \\
\text { (DEXi evaluation } \\
\% \text { of farms) }\end{array}$ & $\begin{array}{l}\text { Organic farms } \\
\text { (DEXi evaluation } \\
\% \text { of farms) }\end{array}$ \\
\hline \multirow[t]{2}{*}{ Family farm } & Property structure & $\begin{array}{l}\text { Unperspective- } 35.3 \\
\text { Less perspective-17.7 } \\
\text { Perspective-11.7 } \\
\text { Very perspective-35.3 }\end{array}$ & $\begin{array}{l}\text { Unperspective-16.7 } \\
\text { Less perspective-3.3 } \\
\text { Perspective-30.0 } \\
\text { Very perspective-50.0 }\end{array}$ \\
\hline & Farm family & $\begin{array}{l}\text { Unperspective- } 23.5 \\
\text { Less perspective- } 0.0 \\
\text { Perspective- } 35.3 \\
\text { Very perspective- } 41.2\end{array}$ & $\begin{array}{l}\text { Unperspective- } 13.3 \\
\text { Less perspective- } 0.0 \\
\text { Perspective- } 46.7 \\
\text { Very perspective- } 40.0\end{array}$ \\
\hline \multirow[t]{2}{*}{ Farm operator } & Personal characteristics & $\begin{array}{l}\text { Inappropriate- } 35.3 \\
\text { Less appropriate- } 0.0 \\
\text { Appropriate- } 0.0 \\
\text { Very appropriate- } 64.7\end{array}$ & $\begin{array}{l}\text { Inappropriate-23.3 } \\
\text { Less appropriate- } 0.0 \\
\text { Appropriate-10.0 } \\
\text { Very appropriate- } 66.7\end{array}$ \\
\hline & Plans, opinions & $\begin{array}{l}\text { Inappropriate-47.1 } \\
\text { Less appropriate-0.0 } \\
\text { Appropriate- } 35.3 \\
\text { Very appropriate-17.6 }\end{array}$ & $\begin{array}{l}\text { Inappropriate- } 30.0 \\
\text { Less appropriate- } 0.0 \\
\text { Appropriate- } 43.3 \\
\text { Very appropriate-26.7 }\end{array}$ \\
\hline Successor & & $\begin{array}{l}\text { No- } 23.5 \\
\text { Probably-70.6 } \\
\text { Yes-5.9 }\end{array}$ & $\begin{array}{l}\text { No-30.0 } \\
\text { Probably-53.3 } \\
\text { Yes-16.7 }\end{array}$ \\
\hline
\end{tabular}


In many European countries, organic farming seems to be a part of a general agriculture strategy for farmers' survival (Michelsen et al., 2001). Organic farms are able to compete financially with conventional farms, with equal or higher profits in most cases (Offerman and Nieberg, 2008). But the long-term survival of the family farm does not only depend on its current financial position but also on its succession status. During the long process of farm succession, farm operators plan a transfer of knowledge, skills, management, tradition and ownership of the farm business from retirement to the next generation (Fennell, 1981). Without a well-derived farm succession process farms often fall into decay.

In this paper, the multi-attribute decision model DEXi is developed in order to find out whether organic farms have a better present succession status than the conventional ones or not.

The results of the model indicate that organic farms received a better succession status evaluation. More than $29 \%$ of conventional farms received the worst evaluation, "very bad" succession status, in contrast to only $10 \%$ of organic farms. Although a similar share of both groups of farms got the best evaluation of their succession status, "very good" (35.5\% of conventional and $36.7 \%$ of organic farms), only $6 \%$ of conventional farms were evaluated as "good" in contrast to $40 \%$ of organic farms. The Chi-square test result revealed that differences are statistically significant $(\mathrm{p}<0.05)$. According to the model structure, the differences indicated that organic farms have a better property and family structure and a larger share of definitively declared successors. The important difference between organic and conventional farms lies also in farmers themselves. The results reveal that "organic" farmers believe more in farming as a way of living and in the future of family farming than their counterparts from conventional farms.

Succession is the problem of many Slovenian farms and therefore the Slovenian Rural Development Program also provides two measures that could promote this process: Setting up of young farmers and Early retirement scheme. At the same time, the process of entry into organic farming is sluggish. The results of our paper, although obtained on a small sample of farms since it is only a pilot study, suggest that favorable succession status and organic farming are treading together, hand in hand. It may be therefore reasonable to establish a political measure, involving all three factors at the same time: setting up of young farmers, early retirement and conversion into organic agriculture. This would improve the succession status on Slovenian farms as well as facilitate entry to an environmentally friendly farming practice. 
DRUŠ. ISTRAŽ. ZAGREB BR. 4 (114),

STR. 1183-1199

BOHAK, Z., BOREC, A. TURK, J.:

SUCCESSION STATUS. GOD. 20 (2011),

In the future, we recommend the development of a more accurate and more thorough model for succession status evaluation, based on the data of a larger number of farms, since the presented multi-attribute decision methodology has been proved as useful. The model could become a welcome information tool for farmers to evaluate the possibilities of their farms to be successfully passed on to the next generation in the future. After a detailed analysis of the model results, farmers could be able to determine what changes in the future would be appropriate in order to increase the probabilities for family farm succession (e.g. change the production type, choose another successor, etc.).

\section{REFERENCES}

Barbič, A. (1991), Kmetov vsakdan: položaj in prihodnost družinskih kmetij na Slovenskem, Ljubljana, Cankarjeva založba.

Barbič, A. (2005), Izzivi in priložnosti podeželja, Ljubljana, Fakulteta za družbene vede.

Bohak, Z. (2006), Nasledstvo in primerjava kmetij z in brez naslednika $v$ občinah Gorišnica, Destrnik in Trnovska vas (Graduation thesis), Maribor, Univerza v Mariboru, Fakulteta za kmetijstvo.

Bohanec, M. (2008), DEXi: Program for Multi-Attribute Decision Making, User's Manual, Version 3.00. IJS Report DP-9989. Ljubljana, Jožef Stefan Institute. http://www-ai.ijs.si/MarkoBohanec/pub/DEXiManual30p. pdf (26. 10. 2009)

Bohanec, M. and Rajkovič, V. (1990), DEX: An Expert System Shell for Decision Support. Sistemica, 1 (1): 145-157.

Bohanec, M. and Rajkovič, V. (1999), Multi-Attribute Decision Modeling: Industrial Applications of DEX. Informatica, 23 (4): 487-491.

Bohanec, M., Zupan, B. and Rajkovič, V. (2000), Applications of Qualitative Multi-Attribute Decision Models in Health Care. International Journal of Medical Informatics, 58-59 (1): 191-205. doi:10.1016/S13865056(00)00087-3

Calus, M., Van Huylenbroeck, G. and Van Lierde, D. (2008), The Relationship between Farm Succession and Farm Assets on Belgian Farms. Sociologia Ruralis, 48 (1): 38-56. doi:10.1111/j.1467-9523.2008.00448.x

Cederberg, C. and Mattsson, B. (2000), Life Cycle Assessment of Milk Production - a Comparison of Conventional and Organic Farming. Journal of Cleaner Production, 8 (1): 49-60. doi:10.1016/S0959-6526(99) 00311-X

Chamberlain, D. E., Wilson, J. D. and Fuller, R. J. (1999), A Comparison of Bird Populations on Organic and Conventional Farm Systems in Southern Britain. Biological Conservation, 88 (3): 307-320. doi:10.1016/ S0006-3207(98)00124-4

Dežman, M. (1988), Nasledstvo na slovenskih kmetijah (Graduation thesis), Ljubljana, Univerza v Ljubljani, Biotehniška fakulteta.

Errington, A. J. (1998), The Intergenerational Transfer of Managerial Control in the Farm-Family Business: A Comparative Study of En- 
DRUŠ. ISTRAŽ. ZAGREB GOD. 20 (2011), BR. 4 (114)

STR. 1183-1199

BOHAK, Z., BOREC, A., TURK, J.:

SUCCESSION STATUS. gland, France and Canada. Journal of Agricultural Education and Extension, 5 (2): 123-136. doi:10.1080/13892249885300241

Fennell, R. (1981), Farm Succession in the European Community. Sociologia Ruralis, 21 (1): 19-42. doi:10.1111/j.1467-9523.1981.tb00290.x

Gasson, R. and Errington, A. J. (1993), The Farm Family Business, London, Wallingford, CAB International.

Glauben, T., Tietje, H. and Weiss, C. (2004), Succession in Agriculture: A Probit and a Competing Risk Analysis. Department of Food Economics and Consumption Studies at the University of Kiel, Kiel. (Working paper FE 0406). http://www.food-econ.uni-kiel.de/Working paper/ FE0406.pdf (19. 3. 2008)

Hole, D. G., Perkins, A. J., Wilson, J. D., Alexander, I. H., Grice, P. V. and Evans, A. D. (2005), Does Organic Farming Benefit Biodiversity? Biological Conservation, 122 (1): 113-130. doi:10.1016/j.biocon.2004.07.018

Jereb, E., Bohanec, M. and Rajkovič, V. (2003), DEXi - Računalniški program za večparametrsko odločanje, Kranj, Moderna organizacija.

Kerbler, B. (2003), Zasnova razvojne tipologije hribovskih kmetijskih gospodarstev: na primeru občine Ribnica na Pohorju. Acta Geographica Slovenica, 43 (2): 87-120. doi:10.3986/AGS43203

Kerbler, B. (2007), Povezanost nasledstva na hribovskih kmetijah v Sloveniji z njihovo socialnogeografsko strukturo (Ph. D. thesis), Ljubljana, Univerza v Ljubljani, Filozofska fakulteta.

Kimhi, A. and Nachlieli, N. (2001), Intergenerational Succession on Israeli Family Farms. Journal of Agricultural Economics, 52 (2): 42-58. doi:10.1111/j.1477-9552.2001.tb00924.x

Kovačič, M. (1996), Socio-ekonomska in velikostna struktura kmetij v Sloveniji v obdobju 1981-1991, Ljubljana, Univerza v Ljubljani, Biotehniška fakulteta.

Lansink, A. O., Pietola, K. and Bäckman, S. (2002), Efficiency and Productivity of Conventional and Organic Farms in Finland 1994-1997. European Review of Agricultural Economics, 29 (1): 51-65. doi:10. 1093/erae/29.1.51

Marušič, J., Ogrin, D. and Maligoj, T. (1993), Značilni krajinski vzorci Slovenije. In: Ž. Mejač (Ed.), Tipološka klasifikcija krajine = Typological Landscape Classification (pp. 9-14), Ljubljana, Institute for Landscape Architecture and Office of the Republic of Slovenia for Physical Planning.

Mäder, P., Fliessbach, A., Dubois, D., Gunst, L., Fried, P. and Niggli, U. (2002), Soil Fertility and Biodiversity in Organic Farming. Science, 296 (5573): 1694-1697.

Michelsen, J. (1996), Organic Farmers and Conventional Distribution Systems: The Recent Expansion of the Organic Food Market in Denmark. American Journal of Alternative Agriculture, 11 (1): 18-24. doi:10. 1017/S0889189300006676

Michelsen, J., Lynggaard, K., Padel, S. and Foster, C. (2001), Organic Farming Development and Agricultural Institutions in Europe: A Study of Six Countries, Stuttgart, Hohenheim, Universität Hohenheim.

Oehl, F., Sieverding, E., Mäder, P., Dubois, D., Ineichen, K., Boller, T. and Wiemken, A. (2004), Impact of Long-Term Conventional and 
DRUŠ. ISTRAŽ. ZAGREB GOD. 20 (2011) BR. 4 (114),

STR. 1183-1199

BOHAK, Z., BOREC, A. TURK, J.:

SUCCESSION STATUS.
Organic Farming on the Diversity of Arbuscular Mycorrhizal Fungi. Oecologia, 138 (4): 574-583. http://www.springerlink.com/content/c5ckd6 alur3ltc0x/ (6. 4. 2010) doi:10.1007/s00442-003-1458-2

Offermann, F. and Nieberg, H. (2008), Does Organic Farming Have a Future in Europe? EuroChoices, 1 (2): 12-17.

Olesen, J. E., Schelde, K., Weiske, A., Weisbjerg, M. R., Asman, W. A. H. and Djurhuus, J. (2006), Modelling Greenhouse Gas Emissions from European Conventional and Organic Dairy Farms. Agriculture, Ecosystems E Environment, 112 (2-3): 207-220. doi:10.1016/j.agee.2005. 08.022

Pažek, K. and Rozman, Č. (2007a), The Simulation Model for Cost-Benefit Analysis on Organic Farms. Agronomski glasnik, 69 (3): 209-222.

Pažek, K. and Rozman, Č. (2007b), The Decision Support System for Supplementary Activities on Organic Farms. Agricultura, 5 (1): 15-20.

Potter, C. and Lobley, M. (1992), Ageing and Succession on Family Farms: The Impact on Decision-Making and Land Use. Sociologia Ruralis, 32 (2-3): 317-334. doi:10.1111/j.1467-9523.1992.tb00935.x

Rozman, Č., Potočnik, M., Pažek, K., Borec, A., Majkovič, D. and Bohanec, M. (2009), A Multi-Criteria Assessment of Tourist Farm Service Quality. Tourism Management, 30 (5): 629-637. doi:10.1016/ j.tourman.2008.11.008

Stopes, C., Lord, E. I., Philipps, L. and Woodward, L. (2002), Nitrate Leaching from Organic Farms and Conventional Farms Following Best Practice. Soil Use and Management, 18 (1): 256-263. doi:10.1111/ j.1475-2743.2002.tb00267.x

Triantaphyllou, E. (2000), Multi-Criteria Decision Making Methods: A Comparative Study, Dordrecht, Kluwer Academic Publishers.

\section{Nasljeđivanje obiteljskih gospodarstava s ekološkom i konvencionalnom proizvodnjom u jugozapadnoi Sloveniji}

Zarja BOHAK, Andreja BOREC, Jernej TURK

Fakultet za poljoprivredu i biosistemske znanosti, Hoče, Slovenija

Da bi se osigurao dugoročni opstanak obiteljskih poljoprivrednih gospodarstava, pitanje nasljeđivanja obiteljskoga gospodarstva od vitalne je važnosti. To je složen proces, u kojem mnogi čimbenici utječu na prijenos obiteljskoga poljoprivrednoga gospodarstva sa starijih generacija na mlađe. Osim toga, organska poljoprivreda postaje sve važniji čimbenik opstojnosti obiteljskoga gospodarstva. Cilj rada jest analiza 17 obiteljskih poljoprivrednih gospodarstava s konvencionalnom i 30 gospodarstava s ekološkom proizvodnjom na jugozapadnom području Slovenije s obzirom na njihov trenutačni status nasljeđivanja, kako bi se ustanovilo koja skupina 
DRUŠ. ISTRAŽ. ZAGREB GOD. 20 (2011),

BR. $4(114)$

STR. 1183-1199

BOHAK, Z., BOREC, A., TURK, J.:

SUCCESSION STATUS...
Metodologija se temelii na tehnici analize odluke, metodologiii DEX te ekspertnom sustavu za modeliranje i podršku. Razvijen je višekriterijski model za istraživanje i analizu podataka, dobivenih standardiziranim upitnicima o procesu naslieđivanja gospodarstva. Rezultati potvrđuju našu pretpostavku i pokazuju da obiteljska gospodarstva s ekološkom proizvodnjom imaju bolii status nasljeđivanja.

Ključne riječi: nasljeđivanje obiteljskoga gospodarstva ekološke farme, metodologija DEX, višekriterijski model za odlučivanje

\section{Organisch und herkömmlich bewirtschaftete Familiengüter in Südwestslowenien und ihre Vererbung}

Zarja BOHAK, Andreja BOREC, Jernej TURK

Fakultät für Landbau und Biowissenschaften, Hoče, Slowenien

Um die Existenz eines landwirtschaftlichen Familienhofes langfristig zu sichern, ist die Frage seiner Vererbung von vitaler Bedeutung. Bei diesem komplexen Vorgang sind viele Faktoren zu berücksichtigen, die bei der Übernahme eines landwirtschaftlichen Familienbetriebs durch die jüngere Generation wirksam in Erscheinung treten. Dabei erweist sich auch die organisch betriebene Landwirtschaft als immer wichtigeres Element, das den Fortbestand und die Nachhaltigkeit eines Familienhofes beeinflussen kann. Im vorliegenden Artikel werden 17 konventionell sowie 30 organisch bewirtschaftete Familiengüter in Südwestslowenien untersucht - stets mit Blick auf ihre Vererbung an die jüngere Generation und die Frage, welche Art der Bewirtschaftung die besseren Zukunftsaussichten hat. Zum Einsatz kommen hierbei eine Analyse entsprechender, von den Bavern getroffener Entscheidungen, Vorgaben der DEXMethodologie sowie ein besonderes System zur Modellierung und Unterstützung. Die Verfasser entwickelten eigens ein auf vielfachen Kriterien gründendes Modell zur Untersuchung und Analyse von Daten, die anhand einer standardisierten Umfrage zum Erbschaftsvorgang gewonnen wurden. Die Ergebnisse bestätigen die Ausgangshypothese der Autoren und zeigen, dass organisch bewirtschaftete Familiengüter einen besseren Status bei Erbangelegenheiten haben.

Schlüsselbegriffe: Familienhöfe und ihre Vererbung, Biofarmen, DEX-Methodologie, Umfragebogen mit vielfachen Kriterien zur Ermittlung von Entscheidungen 